\title{
Adolescent growth and its relation to menarche, dental and somatic maturation
}

\author{
Maria Kaczmarek \\ Institute of Anthropology, Adam Mickiewicz University, Fredry 10, 61-701 \\ Poznań, Poland; E-mail: makac@amu.edu.pl
}

\begin{abstract}
Relationships between growth in height during adolescence and menarche, somatic, and dental maturation were analyzed on longitudinal data for 181 boys and 176 girls from the Poznan Growth Study. It was found that the correlation pattern between variables shifts during the spurt indicating the following regularities: The younger and smaller the boys and girls were at the onset of the spurt, and the lower the height velocity at that time, the longer their spurt was likely to last, and the adolescent height increment was larger. Neither the timing of the spurt, nor the spurt duration or height gain had an influence on the final height. The maturation of the dentition was weekly, or no significantly, correlated with growth in height. The age at menarche revealed significant correlations with all characteristics of the growth spurt except for adolescent increment and adult height.
\end{abstract}

KEY WORDS adolescent spurt, growth curves, physiological maturity

Prz. Antropol. - Anthropol. Rev. (2002), vol. 65, pp. 27-42, Figs. 5, Tables 5. ISBN 83-8696-80-6, ISSN 0033-2003

\section{Introduction}

The complex process of physical development involves quantitative increase in size or mass and a progression of changes, either quantitative or qualitative, that lead to the final, highly organized, matured form. The adolescent growth spurt contributes considerably to this process, although its importance in determining variation in adult size has long been a matter of debate. Several studies suggest that early matures are taller at maturity and have greater mag- nitude of peak of height velocity than later matures, but that the differences in stature may not carry through to adulthood [TANNER 1989, LOPEZ-BLANCO et al. 1995]. There are many reports indicating no relationship between adult stature and the timing of critical points of the adolescent growth spurt, or with the spurt duration, or height gain [ZACHARIAS and RAND 1983, PRADER 1984, BIELICKI and HAUSPIE 1994, SHEEHY et al. 2000]. It is concluded that most characteristics of the growth spurt in stature are under a strong genetic control that appears inde- 
pendent of the genetic control of adult stature [HAUSPIE et al. 1991, BEUNEN et al. 2000]. Furthermore, it is well documented that there exists a general maturity factor during adolescence as can be derived from the interrelationship between various measures of maturation [BIELICKI 1975, 1976; BIELICKI et al. 1984].

There is a considerable variation within and between each sex in the timing, tempo and sequence of biological changes during adolescent growth. Considering sex difference in the timing of the growth spurt in stature, it might be seen that girls are advanced, on the average, by about two years in the initiation of the spurt and more than two years in the age at peak height velocity. The standard deviation of the age at the timing of the spurt yields about one year both in girls and boys [ZACHARIAS and RAND 1983, MALINA et al. 1988, GASSER et al. 2000]. However, careful examination of the data indicates that the magnitude of variation differs between groups.

The present paper aims to describe the pattern of variability in adolescent growth in stature and to determine the degree of relationships between measures of adolescent growth in stature, somatic, dental and sexual maturation.

\section{Materials and methods}

The sample was taken from the longitudinal Poznań Growth Study conducted between 1985 and 1998. The boys and girls were born in 1980 in Poznań and grew up in middle-class socio-economic conditions. Investigations were carried out twice a year, always in the middle of March and September, and covered the age from 5 to 18 years. The final height was considered as that at the age of 18 years. In our sample $98.1 \%$ of boys and $99.8 \%$ of girls examined had completed their adult stature at 18 years of age as judged by an increase in height of less than $1 \mathrm{~cm}$. The initial sample comprised 260 boys and 254 girls. Due to random "loss" of individuals, the final sample size used for the purpose of this paper consisted of 181 boys and 176 girls. A detailed description of the design and data sample of the Poznan Growth Study has previously been published [KACZMAREK 1995a,b, 2001].

For most of the investigation standing body height was measured by the author. The estimated value of intra-TEM was $0.42 \mathrm{~cm}$. In the final part of the investigation two persons were involved in taking height measurements. The value of the inter-TEM was $0.62 \mathrm{~cm}$. The resulted intra- and inter- TEM do not differ from those figures cited in the literature [MALINA et al. 1973, CAMERON 1984, ULIJASZEK and STRICKLAND 1993]. Growth pattern and critical points of the adolescent growth spurt in height were determined by fitting series of an individual's measurements to the mathematical model.

Measurements of body height, number of permanent teeth and age at menarche were used to assess somatic, dental and female sexual maturity. The rate of somatic maturity was assessed in terms of the age at which the given percentage of adult height and weight was attained: $80 \%, 90 \%$ and $95 \%$. Dental maturity was described in terms of two critical points - the ages at which the emergence of 12 and 28 permanent teeth were completed. Permanent teeth were counted while emerging in the oral cavity. Sexual maturity in girls was deter- 
mined in terms of age at menarche. The design of the study with halfyearly intervals of investigation contributed to high accuracy of a girl's report on the age at menarche.

Individual measurements of height and height increments were fitted to the JPA2 structural model [JOLICOEUR et al. 1992]. In this model human growth pattern in height is assumed to be distinguished by additive, more or less independent, phases of growth: early childhood, middle childhood and adolescence. The mathematical equation of the model consists of 8 parameters that in turn have biological meaning when describing adolescent growth spurt. The fitting was done using the AUXAL program (AUXAL SSI. 1994). The goodness of fit of each individual growth data to the JPA2 model was measured by the residual variance or its square root, the standard error of estimate SEE. The median value of SEE for the JPA2 model yielded $0.424 \mathrm{~cm}$ and was equal to the intra-TEM measurement error for height. It appeared that the data was of an extremely high quality. For the purpose of this study following parameters of the spurt were calculated: age, height status and height velocity at the onset and peak of the adolescent growth spurt. The onset of the spurt (spurt take-off, labeled TO) is determined by the critical point of the growth curve indicating prepubertal minimum of growth velocity. This point means at the same time, a change from childhood to adolescence. The point of the growth curve indicating adolescent maximum growth velocity means the peak of height velocity and is labeled PHV.

Descriptive statistics were calculated for all variables involved in the study; statistical decisions were taken with a $5 \%$ probability of error. The relationships between body height and chronological, menarche and dental ages were described in terms of the Pearson's correlation coefficient. All statistical computations were done with the use of the Statistica 5.5 package.

\section{Results}

\section{Variability in stature growth}

The status and tempo of growth in height in terms of the means and standard deviations at successive ages are presented in Figure 1. There is a continuing increase in height attained at successive chronological ages. Considering the height velocity curve, one sees a marked acceleration in growth of height for a period of about two years in adolescence, reaching its maximum rate in growth velocity at the point of peak height velocity of the spurt (PHV). After the PHV, the growth slows down, and when there is little distance left to adult stature, the tempo of growth decelerates attaining less than $1 \mathrm{~cm} /$ year. This is the point when mature size is attained by the end of growth.

There is a clear pattern of changes in the magnitude of variation of stature over growth cycle, as is shown in Figure 2 where coefficients of variation in height and height velocity are plotted against age. Both sexes clearly show that in middle childhood the magnitude of variability in height status is maintained on a steady level. It is followed by a progressive rise that tends to reach an asymptote just before adolescence. Adolescence is associated with a great rise in variation. It is well to envisage 


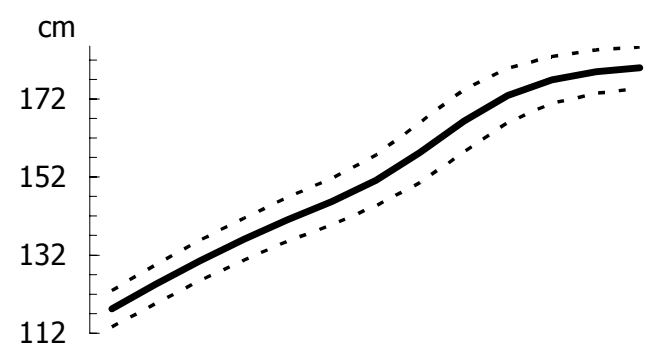

boys

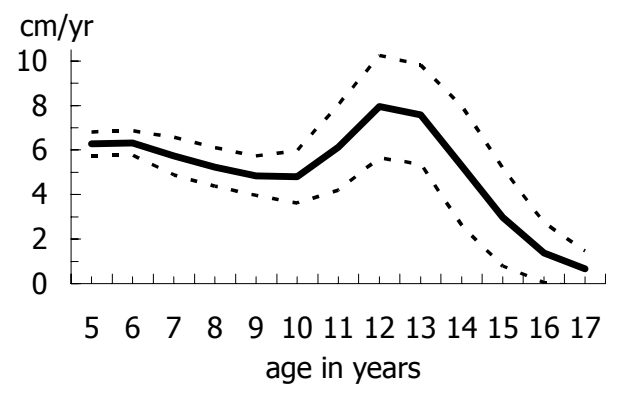

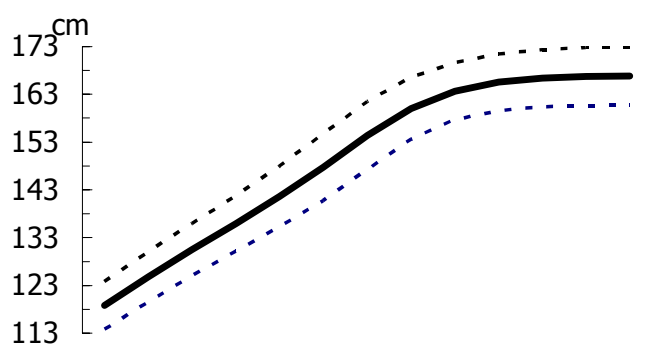

girls

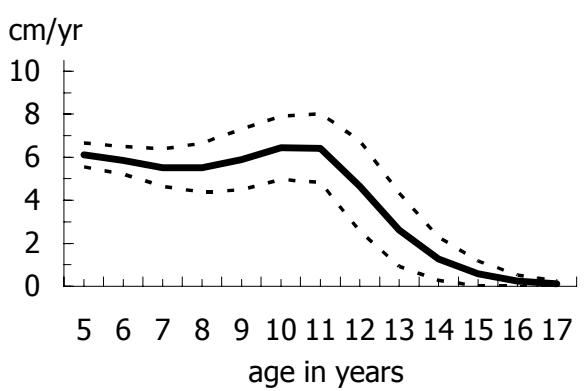

Fig. 1. Age changes in height status and height velocity. Arithmetic means are marked by solid lines, standard deviations by dotted lines.
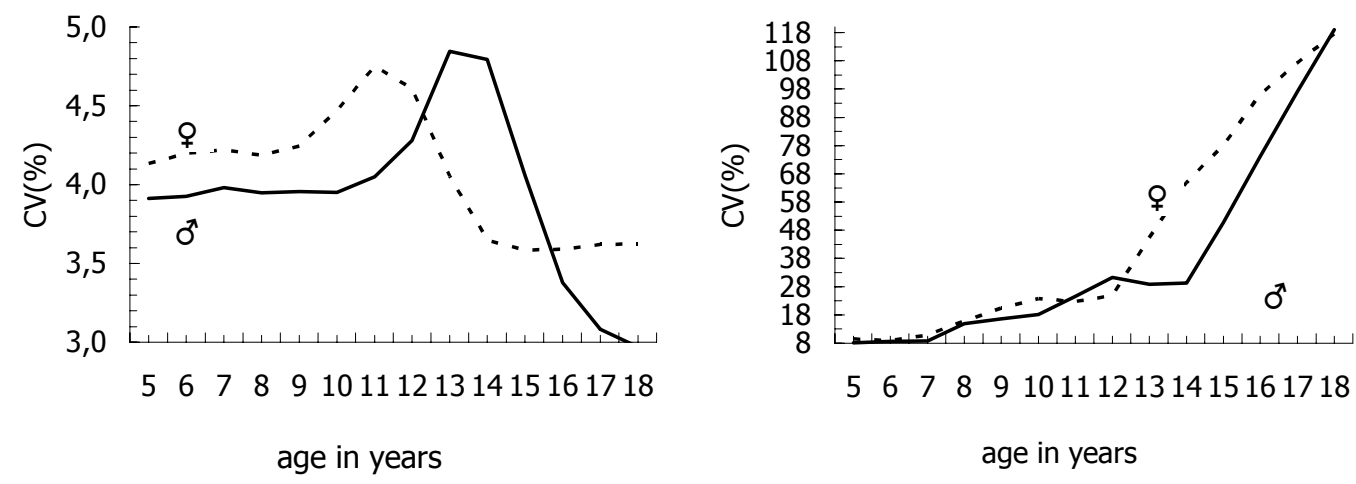

Fig. 2. Age changes in coefficient of variation in height status and height velocity.

that the variability of height status at one age is likely to determine the variability at the next age thus accumulating its magnitude over time.
When comparing absolute terms of the coefficient of variation in height status and velocity, it may be seen that variability in growth velocity is notably greater 
at all ages. Variability in velocity is extremely high in post adolescence though velocity itself is very low. For both, status and velocity, there is a considerable increase in variability during adolescence. In our sample, the maximum value of the coefficient of variation (CV) of stature was noticed at ages 13-14 years in boys and 11-12 years in girls. The greatest magnitude of variation (SD) in height velocity was noticed at the age of 15 years in boys and 13 years in girls.

The sequential (chronological) attitude towards growth data, taken crosssectionally, reveals some aspects of kinetics of growth providing average values for groups but failing to clarify characteristics of individual's growth spurt such as the slope of the spurt, its peak intensity and so on. To obtain the average value of growth curve parameters for a group of children measured in a long-term period, it is necessary to ascertain the value of these parameters for each individual and then average them. The curve for the group, obtained by fitting the curve to each individual's measurements, is the mean constant curve. Mean constant curves of height and height velocity for boys and girls being studied are presented in Figure 3.

Fitting an individual's height data to the JPA2 model makes it possible to calculate values for height attained and height velocity at critical points of the adolescent growth spurt. Descriptive statistics of those points indicate that, on average, the spurt begins at 10.58 years in boys and at 8.68 years in girls, showing girls in advance of boys by 1.90 years. Boys at take off are taller than girls by about $10 \mathrm{~cm}(143.48 \mathrm{~cm}$ of boys versus $133.60 \mathrm{~cm}$ of girls), and their tempo of growth is smaller $(4.73 \mathrm{~cm} /$ year in boys versus $5.20 \mathrm{~cm} /$ year in girls). The difference in timing of the critical points increases while the spurt proceeds and at PHV reaches 2.21 years. It is followed by the difference in height status, which increases to $12.87 \mathrm{~cm}$ in favor of boys. The intensity of PHV is also greater
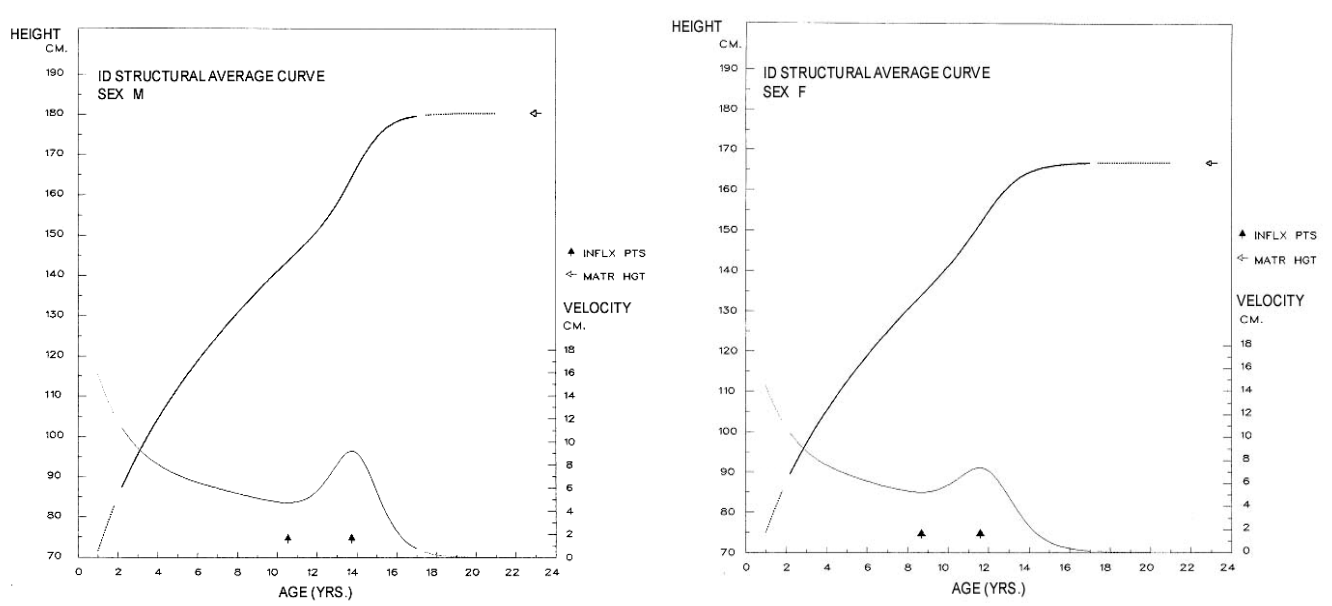

Fig. 3. Mean constant curves of height and height velocity. 


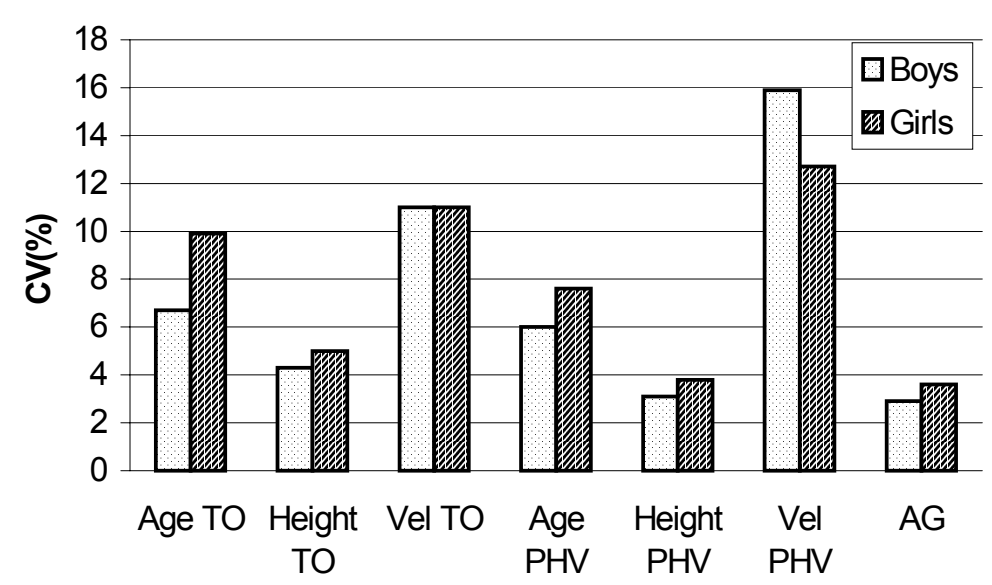

Fig. 4. Coefficient of variation in height and height velocity at critical points of the adolescent growth spurt (TO - spurt onset, PHV - spurt peak, and AG - adolescent gain in height).

in boys than girls: $9.33 \mathrm{~cm} /$ year versus $7.41 \mathrm{~cm} /$ year. Again, the variability is large but a shift has occurred. When measurements are analyzed by specified ages, the greatest range was found at ages 14-15 in boys and 12-13 in girls.

The rate of variation in height and height velocity at critical points of the adolescent growth spurt, presented in terms of coefficient of variation, is shown in Figure 4. Several features should be noticed in this figure. The first is that boys and girls display the same general pattern of variability in critical points of the adolescent growth spurt in height. The pattern indicates the greatest variability of height velocity, followed by moderate variability in timing of the spurt and the relatively smaller variability in height attained at critical points of the spurt. By the end of growth cycle the coefficient of variation yields the smallest value.

The variability of velocity at the onset of the spurt is smaller than that at peak, showing that variability in growth velocity increases while the spurt proceeds. In boys and in girls the coefficient of varia- tion in velocity increases from $\mathrm{CV}_{\text {VelTo }}$ $=11.0$ at take-off to 15.9 in boys and 12.7 in girls at peak. There is a shift in pattern of variability in timing of the spurt. The greater variability in both age and height attained is seen at spurt take off than at spurt peak. The decrease is more pronounced in girls than boys, and is clearly visible when taking the coefficient of variation: $\mathrm{CV}_{\mathrm{AgeTO}}=9.9$ versus $\mathrm{CV}_{\mathrm{AgePHV}}=7.6$ in girls, and $\mathrm{CV}_{\mathrm{AgeTO}}=$ 6.7 versus $\mathrm{CV}_{\mathrm{AgePHV}}=6.0$ in boys.

Considering spurt intensity, the discrepancy between boys and girls increases while the spurt proceeds, showing the difference of $0.47 \mathrm{~cm} /$ year at take off and $1.92 \mathrm{~cm} /$ year at spurt peak. Boys and girls do not differ considerably in height attained at spurt take off and spurt peak. The coefficient of variation in height at take off are slightly greater than that at spurt peak $\left(\mathrm{CV}_{\mathrm{HTO}}=4.3\right.$ in boys and $\mathrm{CV}_{\mathrm{HTO}}=5.0$ in girls; $\mathrm{CV}_{\mathrm{HPHV}}=5.09$ in boys and $\mathrm{CV}_{\mathrm{HPHV}}=3.8$ in girls). It is interesting that girls tend to differentiate more markedly than boys at the age and height attained at both critical points of the spurt, the onset and the peak. 


\section{Variability of indices of maturation}

The rate of somatic maturity was assessed in terms of the age at which $80 \%, 90 \%$ and $95 \%$ of adult height was attained. The corresponding figures are given in Table 1. The contents of the table reveal that the critical points of the adolescent spurt occur at the time when height attained is at a specific percentage of its final value. For example an average onset of the spurt occurs at the time when $80 \%$ of adult height has been attained $(80.0 \%$ in boys and $79.7 \%$ in girls). Height at peak consists of $90 \%$ of adult height $(91.3 \%$ in boys and $90.7 \%$ in girls). The average amount of height gained during adolescence, was 36.86 $\mathrm{cm}$ in boys and $33.39 \mathrm{~cm}$ in girls.

Table 2 gives the corresponding values for height and height velocity at critical points of dental maturity and men-

Table 1. Means, standard deviations and coefficient of variation of age (years), height $(\mathrm{cm})$ and height velocity $(\mathrm{cm} /$ year) at points of percentage attainment of adult height $(\mathrm{AH})$

\begin{tabular}{|c|c|c|c|c|c|c|}
\hline & \multicolumn{3}{|c|}{ Boys } & \multicolumn{3}{|c|}{ Girls } \\
\hline & Mean & SD & $\mathrm{CV}(\%)$ & Mean & SD & CV $(\%)$ \\
\hline \multicolumn{7}{|l|}{ Age } \\
\hline $80 \% \mathrm{AH}$ & 10.72 & 0.93 & 8.7 & 8.64 & 0.72 & 8.3 \\
\hline $90 \% \mathrm{AH}$ & 13.53 & 0.86 & 6.3 & 11.40 & 0.78 & 6.8 \\
\hline $95 \% \mathrm{AH}$ & 14.59 & 1.03 & 7.0 & 12.62 & 0.82 & 6.5 \\
\hline \multicolumn{7}{|l|}{ Height } \\
\hline $80 \% \mathrm{AH}$ & 144.26 & 4.28 & 2.9 & 133.66 & 4.95 & 3.7 \\
\hline $90 \% \mathrm{AH}$ & 162.30 & 4.82 & 2.9 & 150.29 & 5.47 & 3.6 \\
\hline $95 \% \mathrm{AH}$ & 171.31 & 5.09 & 2.9 & 158.64 & 5.78 & 3.6 \\
\hline \multicolumn{7}{|l|}{ Velocity } \\
\hline $80 \% \mathrm{AH}$ & 5.05 & 0.73 & 14.4 & 5.42 & 0.66 & 12.2 \\
\hline $90 \% \mathrm{AH}$ & 9.05 & 1.57 & 17.3 & 7.27 & 0.97 & 13.3 \\
\hline $95 \% \mathrm{AH}$ & 7.52 & 0.90 & 12.0 & 5.92 & 0.55 & 9.3 \\
\hline Adult height & 179.85 & 5.35 & 2.9 & 166.58 & 6.08 & 3.6 \\
\hline Adolescent gain & 36.86 & 5.04 & 13.6 & 33.39 & 4.92 & 14.7 \\
\hline
\end{tabular}

Table 2. Means, standard deviations and coefficient of variation of age (years), height $(\mathrm{cm})$ and height velocity (cm/year) at critical points of dental and sexual maturation

\begin{tabular}{|c|c|c|c|c|c|c|}
\hline & \multicolumn{3}{|c|}{ Boys } & \multicolumn{3}{|c|}{ Girls } \\
\hline & Mean & SD & $\mathrm{CV}$ & Mean & $\mathrm{SD}$ & $\mathrm{CV}$ \\
\hline Menarche age & & & & 12.87 & 0.90 & 6.9 \\
\hline height & & & & 159.23 & 6.29 & 3.9 \\
\hline height velocity & & & & 6.60 & 1.76 & 26.6 \\
\hline 12 teeth age & 8.21 & 0.79 & 9.6 & 7.90 & 0.79 & 10.0 \\
\hline height & 132.05 & 5.27 & 3.9 & 129.08 & 5.48 & 4.2 \\
\hline height velocity & 5.24 & 0.46 & 8.7 & 5.39 & 0.69 & 12.8 \\
\hline 28 teeth age & 12.89 & 1.07 & 8.3 & 12.06 & 1.06 & 8.8 \\
\hline height & 157.85 & 7.49 & 4.2 & 154.46 & 7.08 & 4.6 \\
\hline height velocity & 7.52 & 1.35 & 17.9 & 6.39 & 1.12 & 17.5 \\
\hline
\end{tabular}


A

B
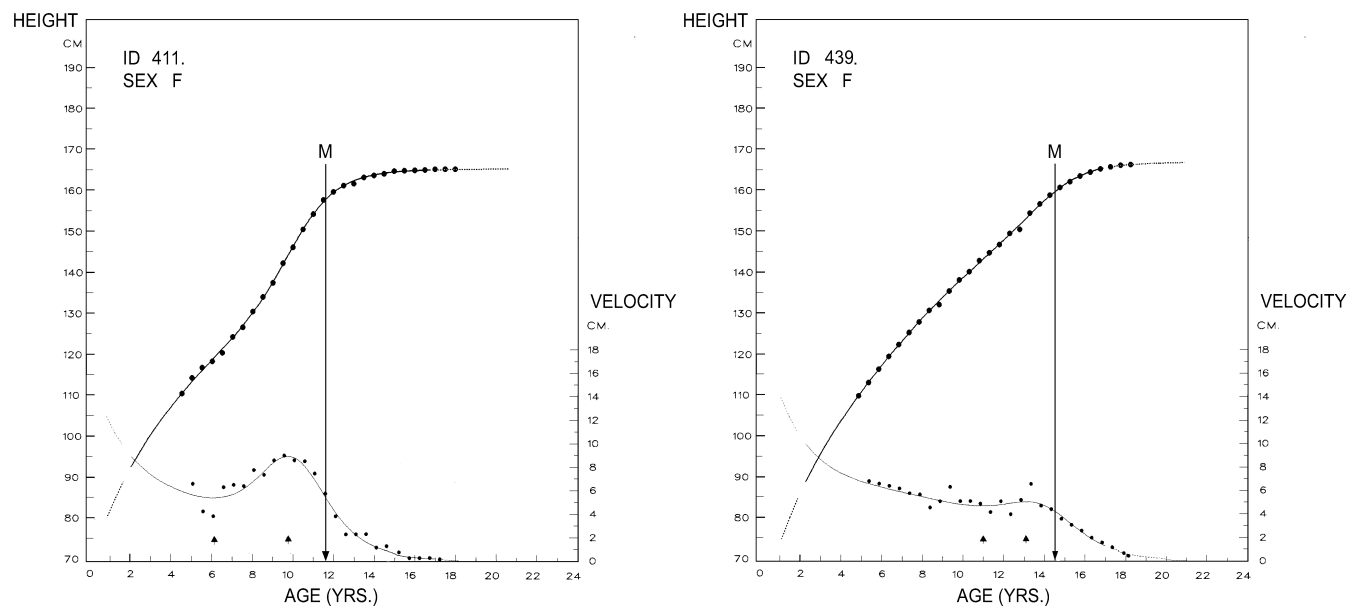

C

D
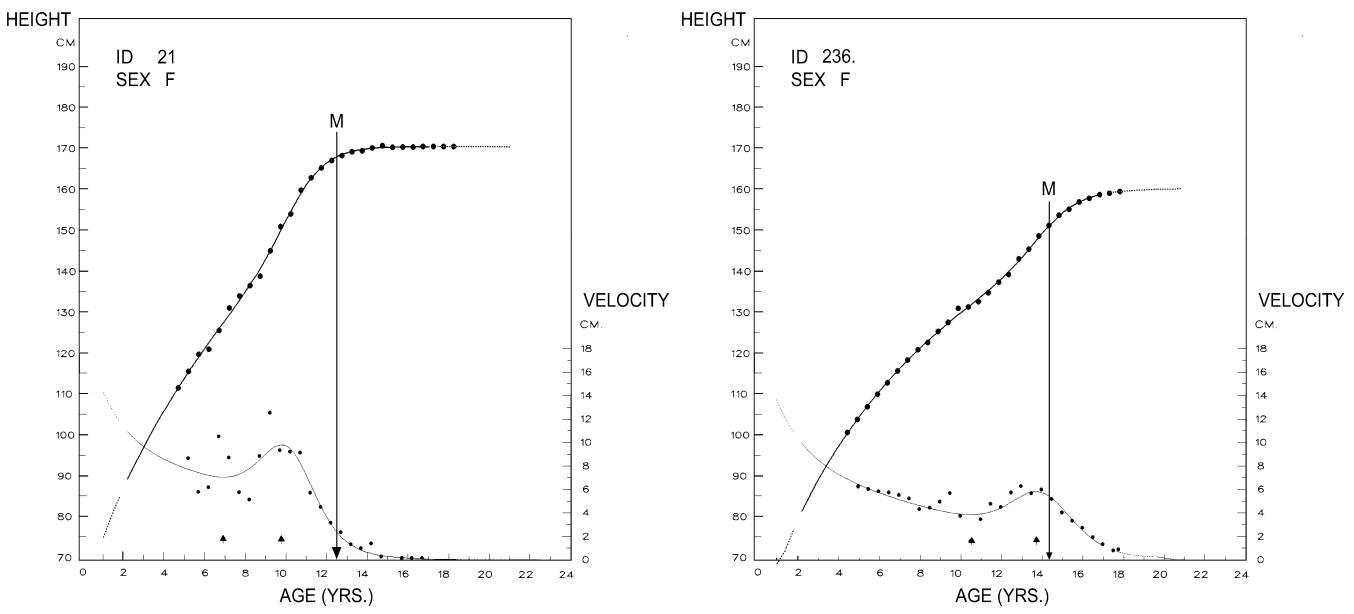

A. (Girl 411): age at TO - 6.27 yrs; age at PHV - 9.91 yrs; age at menarche -11.73 yrs.

B. (Girl 439): age at TO - 10.96 yrs; age at PHV - 13.09 yrs; age at menarche -14.54 yrs.

C. (Girl 21) : age at TO $-6.91 \mathrm{yrs}$; age at PHV $-9.77 \mathrm{yrs}$; age at menarche $-12.35 \mathrm{yrs}$.

D. (Girl 236): age at TO - 10.53 yrs; age at PHV - 13.71 yrs; age at menarche -14.33 yrs.

Fig. 5. Individual growth curves of girls selected for the earliest timing of spurt TO and PHV (A and C) and the latest timing of spurt TO and PHV (B and D). Arrow indicates age at menarche, in each case it occurs after PHV. 
arche. The age at critical points of dental maturity varies to a moderate degree. Slightly larger variation was noticed for the age when 12 teeth were emerged. $\mathrm{CV}_{\text {12TAge }}=9.6$ and 10 for boys and girls. $\mathrm{CV}_{\text {28TAge }}=8.3$ and 8.8 for boys and girls. In considering the range of variation in height status at critical points of dental maturation, it might be seen that the largest variability of all criteria being studied displays height velocity at the ages when 12 and 28 teeth are completed: $\mathrm{CV}_{12 \mathrm{THVel}}=8.7$ in boys versus $\mathrm{CV}_{12 \mathrm{THVel}}=12.8$ in girls. It is worthwhile mentioning that the cessation of permanent teeth emergence usually occurs about one and a half years before PHV in boys whereas, in girls, it proceeds simultaneously to PHV.

The age at menarche ranges from 10.80 years to 15.30 years with the mean at 12.87 years. The coefficient of variation calculated for the age at menarche indicates moderate variation; it figures 6.9. The corresponding mean height at menarche was $159.23 \mathrm{~cm}$ and the mean height velocity $6.60 \mathrm{~cm} /$ year. It was found that menarche always occurred after the maximum height velocity. The average time interval between age at menarche and age at PHV was 1.28 years. In Figure 5 selected examples of the growth curve in height and height velocity are shown. An arrow indicates age at menarche. Girls were selected according to the earliest/latest timing of spurt commencement and spurt peak. In the four cases shown all girls began to menstruate after PHV, irrespective the timing of critical points of the spurt, spurt duration and intensity. A detailed characteristic of each girl's growth spurt is summarized below curves.

\section{Interrelationships among growth variables}

Table 3 lists the correlation coefficients between various characteristics of the critical points of the spurt. Correlation between spurt timing and corresponding height indicate that the later the spurt onsets the taller are the children. However, correlation between spurt onset and height attained decreases as the spurt proceeds to its completion (corresponding values of correlation coefficients are for boys AgeTO-HTO $r=0.43$ and AgeTO-HPHV $r=0.26$ and for girls AgeTO-HTO $r=0.57$ and AgeTOHPHV $r=0.35$ ). It can be clearly seen that the relationships between the variables under question are slightly stronger in girls than in boys although the pattern of interrelationships is the same. The value of final adult height does not depend on the timing, onset, or peak of the spurt (corresponding values of correlation coefficient between those characteristics are very low and range from 0.12 to 0.16 ). Correlation between duration of the spurt and the amount gained in height during adolescence indicates that the smaller children are at the onset of the spurt the longer their spurt is likely to last and they will probably gain the greatest amount of height (the values of correlation coefficients between SDur-HTO $r=-0.50$, SDur-HPHV $r=-0.08$ and correlation coefficient between spurt duration and adolescent gain in height ranges $r=0.77$ in boys and $r=0.79$ in girls. Another interesting correlation reveals that the lower the height velocity at the onset of the spurt the longer it takes to reach peak height velocity (SDur-VelTO $r=-0.34$ for boys and $r=-0.11$ for girls). 
Table 3. Correlation matrix for characteristics of adolescent growth spurt in stature

\begin{tabular}{|c|c|c|c|c|c|c|c|c|c|}
\hline \multicolumn{10}{|c|}{ Boys } \\
\hline & Age TO & H TO & Vel TO & $\begin{array}{l}\text { Age } \\
\text { PHV }\end{array}$ & H PHV & $\begin{array}{c}\text { Vel } \\
\text { PHV }\end{array}$ & S Dur & $\mathrm{AG}$ & $\mathrm{AH}$ \\
\hline Age TO & & .43 & -.56 & .90 & .26 & -.60 & & -.38 & .13 \\
\hline H TO & .57 & & .18 & .13 & .85 & -.48 & -.54 & -.56 & .62 \\
\hline Vel TO & -.73 & -.05 & & -.62 & .34 & .20 & -.34 & .16 & .36 \\
\hline Age PHV & .90 & .34 & -.76 & & .14 & -.36 & & .01 & .16 \\
\hline H PHV & .35 & .87 & .14 & .31 & & -.07 & -.18 & -.05 & .94 \\
\hline Vel PHV & -.60 & -.41 & .37 & -.33 & .01 & & .35 & .80 & .20 \\
\hline S Dur & & -.50 & -.11 & & -.08 & .58 & & .77 & .10 \\
\hline AG & -.62 & -.49 & .48 & -.26 & -.01 & .81 & .79 & & .30 \\
\hline $\mathrm{AH}$ & .12 & .71 & .33 & .16 & .95 & .21 & .09 & .27 & \\
\hline \multicolumn{10}{|c|}{ Girls } \\
\hline
\end{tabular}

Figures above the diagonal refer to boys and below the diagonal to girls.

Abbreviations: AgeTO - age at take-off; HTO - height at take-off; VelTO - velocity at take-off; PHV - peak height velocity; S Dur - spurt duration; AG - adolescent gain; AH - adult height.

Significance: bold $\mathrm{p}<0.01$, standard $\mathrm{p}<0.05$, italic - insignificant.

The above statement holds true only for boys; for girls there is no significant correlation between these variables.

\section{Relationships between growth in height and menarche}

Table 4 presents the correlation coefficients between growth in height in girls and menarche. The magnitudes of correlation coefficients between spurt timing and age at menarche indicate an increase (from $r=0.57$ at the onset of the spurt to $r=0.64$ at spurt peak). It was found that in almost all girls menarche occurred after the maximum height velocity. The mean time interval in the present data was 1.28 years.

Age at menarche is only weakly correlated with height at critical points of the adolescent spurt and reversely correlated with velocity. The earlier the menarche the higher the height velocity. The probability that a girl who grows fast follows the same pattern throughout the spurt increases while the spurt proceeds. The value of correlation coefficients between age at menarche and height velocity decreases from $r=-0.42$ at spurt onset to $r=-0.28$ at spurt peak. The correlation between age at menarche and height at TO is $r=0.22$ and at PHV $r=0.20$. Age at menarche does not depend on the height attained. Height at adulthood is also not correlated with age at menarche. The coefficient of correlation between age at menarche and the adult height is very low, $r=0.12$.

Table 4. Coefficients of correlation between characteristics of growth spurt in height and age at menarche in girls

\begin{tabular}{lc}
\hline Characteristics & Age at menarche \\
\hline Age TO & $\mathbf{0 . 5 7}$ \\
H TO & $\mathbf{0 . 2 2}$ \\
Vel TO & $\mathbf{- 0 . 4 2}$ \\
Age PHV & $\mathbf{0 . 6 3}$ \\
H PHV & 0.20 \\
Vel PHV & $\mathbf{- 0 . 2 8}$ \\
S Dur & $\mathbf{0 . 2 0}$ \\
AG & -0.14 \\
AH & 0.12 \\
\hline
\end{tabular}

All the abbreviations are the same as in Table 3. Significance: bold $\mathrm{p}<0.01$, standard $\mathrm{p}<0.05$, italic - insignificant. 


\section{Relationships between growth in height and dental age}

Maturity rate of the dentition was measured in terms of the age when 12 and then 28 permanent teeth had emerged. These two events are regarded as critical points of dental maturation. Coefficients of correlation between characteristics of the growth spurt in height and ages when 12 and 28 permanent teeth had emerged (Age 12T and Age 28T, respectively) are presented in Table 5. Correlation coefficients for relations between dental maturity and the onset of the growth spurt and height at specified ages indicate very low correlation coefficients between growth and dental maturity. Dental maturity does not depend on the timing of the spurt nor the height attained at critical points of dental maturity. Corresponding values of correlation coefficients range from $r=-0.22$ between age at $12 \mathrm{~T}$ and height at TO to $r=-0.15$ for the other characteristics.

Table 5. Coefficients of correlation between characteristics of growth spurt in height and dental age

\begin{tabular}{lrrrr}
\hline & \multicolumn{2}{c}{ Boys } & \multicolumn{2}{c}{ Girls } \\
\hline & Age 12T & Age 28T & Age 12T & Age 28T \\
\hline Age TO & -0.08 & 0.12 & 0.06 & 0.16 \\
H TO & $\mathbf{- 0 . 2 2}$ & -0.16 & $\mathbf{- 0 . 1 5}$ & -0.10 \\
Vel TO & -0.04 & $\mathbf{- 0 . 2 1}$ & -0.15 & -0.20 \\
Age & 0.07 & 0.16 & 0.17 & $\mathbf{0 . 2 0}$ \\
PHV & & & & \\
H PHV & -0.20 & -0.16 & -0.06 & -0.12 \\
Vel & 0.17 & -0.04 & 0.13 & -0.03 \\
PHV & & & & \\
AG & 0.12 & 0.03 & 0.14 & -0.06 \\
AH & -.07 & -0.13 & -0.04 & -0.16 \\
\hline
\end{tabular}

All the abbreviations are the same as in Table 3 .

Significance: bold $\mathrm{p}<0.01$, standard $\mathrm{p}<0.05$, italic - insignificant.

\section{Discussion}

Attempts at describing various aspects of relationships between measures of growth and maturation have been undertaken in many ways, since the pioneering works of Boas and Shuttleworth in the thirties (cited in TANNER [1962]) to date. Longitudinal data are required to identify the changes in growth pattern and in growth velocity as well as the magnitude and pattern of variability in biological characteristics of the growth spurt. Mathematical models applied for smoothing individual's growth curve have opened out new perspectives for comparative studies of characteristics of the growth curve and relationships between growth and maturation.

Generally, our data are in good agreement with the findings of BIELICKI and WALISZKO [1975], WALISZKO and JEDLIŃSKA [1976], CHRZĄSTEK-SPRUCH et al. [1990], GEITHNER et al. [1999] and others. The discrepancy of our data occurred at the age of initiation of the adolescent growth spurt in girls. In our sample, the initiation of the spurt occurs at 8.7 years, i.e., almost one year earlier compared with Wrocław sample. It seems that differences among estimates relate partly to biological phenomena and partly to methodological differences in deriving them. Some are derived from mathematically fitted curves while others are derived from visual estimates on graphically fitted curves.

In our sample the degree of variability demonstrates some distinctive patterns of variability in stature with growth. The degree of variability shifts with the change of context of the data. When the data were taken in chronological context the measurements simply represented 
progressive changes in the postnatal stage of the growth cycle from birth to adulthood. The greatest variability in height status was found at age 12 in girls and 14 in boys. When the context of developmental events, e.g. adolescent growth spurt, was under consideration, the pattern represented the changes in rate of growth which resulted in the growth spurt. The range of individual variation in the timing and magnitude of the adolescent spurt is considerable. Some children begin their adolescent spurt before the age range commonly known for the transition from childhood to adolescence, as in our example for girl 411 who begins the spurt at age 6.27 or girl 21 who reaches PHV at age 9.77. It is one of the interesting aspects of adolescent growth. Is this phenomenon a real biological fact or the result of the growth fitting procedure? In our sample of boys and girls the greatest variability was revealed for PHV and TO velocity, followed by the variability of age and height at spurt onset. The degree of variability of age and height decreases as the spurt proceeds to its completion. Here, our data are in good agreement with the findings of ZACHARIAS and RAND [1983].

Our findings are also in good agreement with those of TANNER et al. [1976], and ZACHARIAS and RAND [1983] concerning values of correlation between estimates of the adolescent spurt. We found a high correlation between timing of the spurt and corresponding height but insignificant correlation between timing of the spurt and adult height. This means that adult height does not depend of the spurt onset or the spurt PHV. Strong relationships were found between height at TO and PHV and the adult height. The degree of correlation increases as the spurt proceeds, as it derives from the magnitude of the correlation coefficient which ranges from 0.62 to 0.95 . Adult height and adolescent gain in height status reveals a highly significant correlation of values that range from 0.30 in boys to 0.27 in girls.

As far as adolescent gain in height is concerned, our findings are similar to those of ZACHARIAS and RAND [1983] and unlike TANNER et al. [1976] who noticed a weak negative correlation (-0.21). Our data reveal a tendency for children who are short at the initiation of the spurt have to grow more to reach adult height. However the same tendency was more strongly emphasized in the data of Zacharias and Rand. HAUSPIE [1980] summarized some correlations between height and characteristics of critical points of the growth curve. Generally they are in a good agreement though some minor discrepancies result probably from a different procedure employed in smoothing growth curve.

The correlation between dental development calculated from the number of erupted permanent teeth and other measures of somatic maturation has been reported as being low to moderate [LEWIS and GARN 1960, BJøRK and HELM 1967]. Correlation between the dental development and the age at peak height velocity was also found to be low. In other studies, however, a high correlation between height growth and dental maturation was demonstrated by FILLIPSSON [1975], and FILLIPSSON and HALL [1976] who applied a new method for the evaluation of dental maturity. The different methodologies, however, preclude ability to make comparisons. 
It has already been stated that the age at menarche is well correlated with the age at PHV [TANNER et al. 1976]. In our data the age at menarche significantly correlates with all characteristics of the spurt. The magnitude of correlation coefficients between the timing of the spurt and the age at menarche ranges from $r=0.57$ at TO to $r=0.63$ at PHV. The strength of the correlation between height at critical points and the age at menarche is evaluated as $r=-0.22$ for height at TO to $r=0.20$ for height at PHV. Moderate and negative correlation was found between height growth velocity and age at menarche.

\section{Conclusions}

Results obtained in this study provide good support for the statement about integration of growth and maturity. This statement may be supported by following conclusions:

1. There is no difference between sex in the pattern of variability in height growth and height velocity. Variability in height status is accumulated over time and notably smaller in absolute terms than the variability in height velocity.

2 . The variability of age and height at critical points of the adolescent growth spurt is greatest at spurt onset and decreases as the spurt proceeds to completion. The largest variability in height velocity occurs at the peak of the spurt.

3. Menarche is related to the critical points of the adolescent growth spurt in such a way that it occurs after the peak of the spurt - the mean time interval is 1.28 years.

4. Dental and somatic maturity are weakly related to each other. On the average, in girls dental development proceeds to its completion at almost the same time as the peak height velocity is reached. In boys it occurs before the peak of the adolescent growth spurt in height.

\section{References}

Beunen G., M. Thomis, H.H. Maes, R. Loos, R.M. Malina, A.L. Claessens, R. VlietincK, 2000 , Genetic variance of adolescent growth in stature, Ann. Hum. Biol., 27, 173-186

BIELICKI T., 1975, Interrelationships between various measures of maturation rate in girls during adolescence, Stud. Phys. Anthropol., 1, 51-64

BIELICKI T., 1976, On the relationship between maturation rate and maximum velocity of growth during adolescence, Stud. Phys. Anthropol., 3, 79-84

BIElicki T, R. HausPie, 1994, On the independence of adult stature from the timing of the adolescent growth spurt, Am. J. Hum. Biol., 6, 245-247

Bielicki T., J. KoniareK, R.M. MaLina, 1984, Interrelationship among certain measures of growth and maturation rate in boys during adolescence, Ann. Hum. Biol., 11, 201-210

Bielicki T., A. Waliszko, 1975, Wrocław Growth Study Part I: Females, Stud. Phys. Anthrop., 2, 53-83

BJørK A., S. Helm, 1967, Prediction of the age of maximum pubertal growth in body height, Angle Orthodontists, 37, 134-143

CAMERON N., 1984, The Measurement of Human Growth, Croom Helm, London \& Sydney

ChrząsteK-Spruch A., C. SusAnNe, R. HAUSPIE, 1990, Standards for height velocity for Polish children, Stud. Hum. Ecol., 9, 179197

FILLIPSSON R., 1975, A new method for the assessment of dental maturity using the individual curve of number of erupted permanent teeth, Ann. Hum. Biol., 2, 13-24

FILLIPSON R., K. HALL, 1976, Correlation between dental maturity, height development and sexual maturation in normal girls, Ann. Hum. Biol., 3, 205-210

Gasser T., A. SheEhy, L. Molinari, R.H. LARGO, 2000, Sex dimorphism in growth, Ann. Hum. Biol., 27, 187-197 
Geithner C., T. SATAKe, B. Woynarowska, R. MalinA, 1999, Adolescent spurts in body dimensions: Average and modal sequences, Am. J. Hum. Biol., 11, 287-295

HaUsPie R., 1980, Adolescent growth, [in:] Human Physical Growth and Maturation, F.E. Johnston, A.F. Roche, C. Susanne (eds.), Plenum Press, New York, pp. 161-175

Hauspie R., T. BIELICKI, J. KoniaReK, 1991, Skeletal maturity at onset of the adolescent growth spurt and at peak velocity for growth in height; A threshold effect?, Ann. Hum. Biol., 18, 23-29

Jolicouer P., J. Pontier, H. ABIDI, 1992, Asymptotic models for longitudinal growth of human stature, Ann. Hum. Biol., 4, 461-468

KaczMarek M., 1995a, Poznańskie badania dlugofalowe. Wzorce $i$ dynamika wyrzynania sie zębów stałych a ocena dojrzałości biologicznej organizmu, Przegląd Antropol., 57, 1-36

KACZMAREK M., 1995b, Wpływ warunków życia na wzrastanie i rozwój człowieka, Wyd. Nauk. UAM, Seria Antropologia, 20, Poznań

KACZMAREK M., 2001, Poznańskie badania longitudinalne. Rozwój fizyczny chłopców $i$ dziewczat, Monografie Instytutu Antropologii UAM, 9, Poznań

LOPEZ-Blanco M., I. IZAGUIRRE-ESPinOZA, C. Macias-TomeI, L. SAAB-VERARdy, 1995, Growth in stature in early and late maturing children of the Caracas mixed-longitudinal study, Am. J. Hum. Biol., 7, 517-527

LEWIS A., S. GARN, 1960, The relationship between tooth formation and other maturational factors, Angle Orthodontist, 30, 70-77

Malina R.M., P.V. Hamill, S. Lameshow, 1973, Selected Body Measurements of Children
6-11 Years, United State Vital and Health Statistics, Ser. 11, No. 123, US Government Printing Office, Washington

Malina R.M., C. Bouchard, G. BEunen, 1988, Human growth: Selected aspects of current research on well-nourished children, Ann. Rev. Anthropol., 17, 187-219

PRADER A., 1984, Biomedical and endocrinological aspects of normal growth and development, [in:] Human Growth and Development, J. Borms, R. Hauspie, A. Sand, C. Susanne, M. Hebbelinck (eds.), New York, Plenum Press, pp. 1-22

SHEEHY A., T. GASSER, L. Molinari, R.H. LARGO, 2000, Contribution of growth phases to adult size, Ann. Hum. Biol., 27, 281-298

TANNER J.M., 1962, Growth at Adolescence, Oxford, Blackwell Scientific

TANner J.M., 1989, Foetus into Man. Physical Growth from Conception to Maturity, Cambridge, Harvard Univ. Press

TANNER J.M., R.H. Whitehouse, E. MARUbini, L.F. RESELE, 1976, The adolescent growth spurt of boys and girls of the Harpenden Growth Study, Ann. Hum. Biol., 3, 109-126

UliJaszeK S.J., S.S. STRICKLAND, 1993, Nutritional studies in biological anthropology, [in:] Research Strategies in Human Biology, Field and Survey Studies, G.W. Lasker., C.G. MascieTaylor (eds.), Cambridge Univ. Press

WAliszKo A., W. JedLIŃSKA, 1976, Wrocław Growth Study. Part II: Males, Stud. Phys. Anthrop. 3, 27-48

ZaCharias L., W.M. RAND, 1983, Adolescent growth in height and its relation to menarche in contemporary American girls, Ann. Hum. Biol., 10, 209-222

\section{Streszczenie}

Celem pracy było określenie zależności pomiędzy wzrastaniem wysokości ciała w okresie pokwitania a wiekiem menarche, wiekiem zębowym i somatycznym. Współzależności analizowano na podstawie danych dla 181 chłopców i 176 dziewcząt urodzonych w $1980 \mathrm{r}$. w Poznaniu i okolicy, w średniozamożnych rodzinach, uczestniczących w latach 1985-98 w Poznańskich Badaniach Długofalowych. Badania o charakterze ciagłym wykonywano dwukrotnie w ciagu roku, zawsze w połowie marca i września. Objęły one okres od 5. do 18. roku życia. Pomiary antropometryczne wykonywano z dużą rzetelnością. Wyliczona z powtórzeń pomiarów wartość błędu intra-subiektywnego (intra-TEM) dla wysokości ciała 
wyniosła 0,42 cm, natomiast błędu inter-subiektywnego (inter-TEM) 0,62 cm; wartości te są podobne do cytowanych w literaturze [MALINA et al. 1973, CAMERON 1984, ULIJASZEK i STRICKLAND 1993]. Krzywe wzrastania i punkty krytyczne krzywej dla skoku pokwitaniowego wysokości ciała wykreślono w programie AUXAL, dopasowując do serii indywidualnych pomiarów matematyczny model wzrastania, znany w auksologii jako JPA2 [JOLICOEUR i wsp. 1992]. Dopasowanie modelu do danych pomiarowych okazało się bardzo dobre, o czym świadczy standardowy błąd estymacji SEE równy $0,424 \mathrm{~cm}$, tak jak wartość intra-TEM.

Na podstawie wartości współczynników korelacji Pearsona analizowano zależności pomiędzy charakterystykami skoku pokwitaniowego wysokości ciała: wiekiem, osiagniętą wysokością i tempem wzrostu w momencie rozpoczęcia skoku (punkt take off - TO) i szczycie skoku pokwitaniowego (PHV) a miarami dojrzałości fizjologicznej. Stopień dojrzałości somatycznej określono na podstawie wieku, w którym dzieci osiągały odpowiednio: 80\%, 90\% i 95\% wartości ostatecznej wysokości ciała. Stopień dojrzałości zębowej określono dwoma punktami krytycznymi: jako wiek wyrznięcia się 12 i 28 zębów stałych. Wiek menarche określono na podstawie indywidualnych relacji dziewcząt. Szczegółowy opis metodyki badań można znaleźć we wcześniejszych publikacjach [KACZMAREK 1995a,b, 2001]. Obliczenia statystyczne wykonano w pakiecie Statistica 5.5.

Wzrastanie wysokości ciała w ujęciu chronologicznym, jako krzywe dla średnich arytmetycznych i odchyleń standardowych w kolejnych kategoriach wieku kalendarzowego przedstawia rys. 1. Krzywa tempa wzrastania wykazuje znaczne przyspieszenie w ciagu dwu lat w okresie pokwitania, osiągając największą wartość w szczycie skoku (PHV). Na podstawie krzywych tempa wzrastania można zauważyć, że stopień indywidualnych różnic zmienia się w zależności od analizowanego okresu. Przedstawiając zróżnicowanie indywidualne w formie współczynnika zmienności dla wartości wysokości ciała osiaganych w danym wieku kalendarzowym i przyrostów rocznych (rys. 2) można zauważyć, że w okresie środkowego dzieciństwa zróżnicowanie utrzymuje się na stałym poziomie, wyraźnie natomiast wzrasta w okresie pokwitania. Zróżnicowanie tempa wzrastania wykazuje tendencje do systematycznego wzrastania z wiekiem. Zarówno w przebiegu, jak i tempie wzrastania znaczne zwiększenie różnic indywidualnych przypada na okres pokwitania. Największe wartości współczynnika zmienności (CV) w przebiegu wzrastania wysokości ciała obserwowano w wieku 13-14 lat u chłopców i 11-12 lat u dziewcząt, a w przypadku tempa wzrastania (na podstawie odchylenia standardowego) w wieku 15 lat u chłopców i 13 lat u dziewcząt. Na rys. 3 przedstawiono krzywe średnich wartości stałych wraz z charakterystykami opisowymi punktów krytycznych krzywej, będące przedmiotem dalszej analizy. Dziewczęta prawie dwa lata wcześniej od chłopców rozpoczynają skok pokwitaniowy wysokości ciała a różnica ta zwiększa się wraz z trwaniem skoku i w momencie szczytu wynosi 2,2 lat. Stopień indywidualnych różnic prezentuje rys. 4. Największe zróżnicowanie wykazuje tempo wzrostu w szczycie skoku, umiarkowane w momentach czasowych skoku a najmniejsze w wartościach osiaganej wysokości ciała w punktach krytycznych skoku.

W tabeli 1 przedstawiono statystki opisowe charakteryzujące dojrzałość somatyczną, a w tabeli 2 odpowiednie wartości dla wysokości i tempa wzrastania wysokości ciała i dojrzałości zębowej i wieku menarche. Na podstawie wartości współczynników korelacji Pearsona, pomiędzy charakterystykami skoku pokwitaniowego wysokości ciała a wiekiem somatycznym, zębowym i menarche (zaprezentowanych w tabelach 3, 4 i 5) można wskazać następujące prawidłowości, takie same u chłopców i dziewcząt: im wcześniej rozpoczyna się skok pokwitaniowy tym dłużej trwa osiaganie szczytu skoku, a pokwitaniowy przyrost wysokości ciała jest większy. Moment rozpoczęcia skoku ani też długość trwania skoku nie 
wpływają na wartość ostatecznej wysokości ciała. Stopień dojrzałości zębowej jest bardzo słabo, jeśli w ogóle, skorelowany ze wzrastaniem wysokości ciała. Natomiast istotne korelacje zaobserwowano pomiędzy wiekiem menarche a charakterystykami skoku pokwitaniowego. Najbardziej uderzającą prawidłowością, zilustrowaną na rys. 5 indywidualnymi przypadkami, jest fakt, że menarche pojawia się zawsze po szczycie skoku pokwitaniowego (przeciętnie w 1,28 roku). Stwierdzono, ze ostateczna wysokość ciała nie jest skorelowana $\mathrm{z}$ żadną $\mathrm{z}$ badanych zmiennych. 